\title{
Procesy rewitalizacyjne w mieście jako działanie społeczne na rzecz peryferii
}

\author{
City revitalization processes \\ as a social action for periphery
}

A B S TRACT: The article presents the specificity of cities due to segregation processes, which form a part of the urbanisation structure of a city. These processes are also reflected in the access to basic public services: education, health care, housing, technical communal infrastructure, recreation and security, and this has a fundamental and direct impact on the quality of people's lives. The article shows how, in the social space of the city of Gdynia, it is possible to eliminate the effects of segregation, and what is the significance of revitalisation activities which minimise these effects, but do not, in fact, change this division (social, spatial, cultural). The selected revitalisation projects in Gdynia concern the revitalisation project of the so-called 'Pekin', the second, the revitalisation of the districts Grabówek and Chylonia, and the project 'Utrecht', aimed at homeless people, mostly from 'Pekin', Chylonia, Grabówek, or currently living in these districts. The revitalisation of 'Pekin' is mainly an activity of activating residents in the professional sphere, helping with finding alternative accommodation and financial support with apartment rentals. The entire estate will eventually be demolished. The revitalisation of Chylonia and Grabówek are animation, socio-therapeutic activities, streetworking, pedagogical and psychological counselling, training, volunteering (including international volunteering), organising the local community.

K E Y W O R D S: City, revitalisiation, participation, social forces, social project.

STRESZCZEN IE: W artykule zaprezentowano specyfikę miast ze względu na procesy segregacyjne, które wpisują się w strukturę urbanizacyjną miasta. Procesy te mają swoje odzwierciedlenie w dostępie do podstawowych usług publicznych: edukacji, opieki zdrowotnej, mieszkalnictwa, technicznej infrastruktury 
komunalnej, rekreacji oraz bezpieczeństwa, a to ma zasadniczy i bezpośredni wpływ na jakość życia ludzi. Autorka wskazuje jak w przestrzeni społecznej Gdyni możliwe jest niwelowanie skutków segregacji oraz jakie znaczenie mają działania rewitalizacyjne, które minimalizują skutki, ale tego podziału (społecznego, przestrzennego, kulturowego) de facto nie zmieniają. Jednym z prezentowanych projektów jest projekt rewitalizacji defaworyzowanego osiedla, tzw. „Pekinu”. Kolejnymi będą projekty rewitalizacji dzielnic Grabówka i Chylonia, ostatnim jest projekt o nazwie "Utrecht”. Ostatni skierowany jest on do osób bezdomnym, w większości wywodzących się z "Pekinu”, Chylonii, Grabówka, lub aktualnie zamieszkujących w tych dzielnicach. Rewitalizacja "Pekinu” jest działaniem aktywizowania mieszkańców w sferze zawodowej, oferuje pomoc w znalezieniu innych lokali mieszalnych oraz wsparcie finansowe w wynajmie mieszkań. Całe osiedle zostanie docelowo zburzone. Rewitalizacja Chyloni i Grabówka to działania animacyjne, socjoterapeutyczne, streeworking, poradnictwo pedagogiczne i psychologiczne, szkolenia, wolontariat (także międzynarodowy), organizowanie społeczności lokalnej.

SŁOWA KLUCZOWE: Miasto, rewitalizacja, partycypacja, siły społeczne, projekt socjalny.

Główne wątki dyskursu, które toczą się w obszarze środowiskowej pracy socjalnej i rewitalizacji w mieście, dotyczą ich zasadności, społecznej sprawiedliwości i oczekiwanych rezultatów. Pojawia się wiele pytań o to, które kierunki są słuszne i świadczą o wysokiej kulturze życia społecznego oraz politycznego w naszym kraju. Działania rewitalizacyjne podejmowane w Gdyni są projektami o szerokim spektrum, od rewitalizacji urbanistycznej po społeczną i kulturową, jednak mają na celu poprawę jakości życia mieszkańców, a nie ruchu w kierunku relokacji z miejsc defaworyzowanych czy wykluczających. Wyjątek stanowić będzie tylko jeden z omawianych projektów - rewitalizacja „Pekinu”. Takie działania gminy związane są głównie z przeszkodami prawnymi, gdyż ani gmina Gdynia, ani osoby tam zamieszkujące, nie są właścicielami gruntów. Głos krytyczny w sprawie rewitalizacji prezentuje Maria Mendel, która pisze, że projekty rewitalizacyjne, liczne inicjatywy obywatelskie, które oswajają miejsce, upiększają je, nadal są tylko odtwarzaniem przestrzeni biedy (2017, s. 108). Struktura ludności w głównej mierze pozostaje niezmienna, a rewitalizacja kulturowo-społeczna stanowi niewielki ułamek działań. Warto jednak zadać sobie pytanie czy jest jakiś optymalny kierunek działań rewitalizacyjnych, bo jak pokazują analizy kategorii miasta jako miejsca, segregacja na centrum i peryferia $\mathrm{w}$ mieście są wpisane $\mathrm{w}$ jego tkankę oraz historię.

\section{Centrum i peryferia}

Iwona Sagan zwraca uwagę na fakt, że w przestrzeni miast zawsze istniała segregacja grup społecznych, a grupy znajdujące się na dole drabiny społecznej zwykle były spychane na obrzeża przestrzeni miejskiej, obojętnie ze względów religijnych, etnicznych, kulturowych, ekonomicznych, czy innych 
(Sagan 2017, s. 90). Było tak zarówno w czasach tworzenia się miast średniowiecznych, jest i obecnie, a podział ten się utrzymuje zarówno za sprawą zastanych już i powielanych mechanizmów segregacji oraz mechanizmów rynkowych, które narzucają tę segregację, bowiem ceny nieruchomości i gruntów w centrach są znacznie wyższe (a tym samym niedostępne dla ludzi uboższych), niż ceny na obrzeżach. Cena nieruchomości nie jest stricte związana $\mathrm{z}$ jej ceną realną (nakładu na budowę), ale $\mathrm{z}$ nabyciem dostępu do innych zasobów, takich jak: przyjaciele, praca, zasoby przyrody, szkoły, kultura, prestiż itp. (por. Sagan 2017, 82-83). Dynamiczny proces przenoszenia się ludności ze wsi do miast wskazuje na to, że pojawiają się nowe osiedla na obrzeżach (w przypadku Trójmiasta są to okolice obwodnicy), kształtując inną strukturę urbanizacyjną, jednak cały czas miejsca te wybierają osoby mniej zamożne (ceny mieszkań są tam co najmniej o połowę niższe niż w centrum lub w okolicach skm, która jest łącznikiem $\mathrm{z}$ centrami). Zaobserwować można również, że chętniej mieszkania na obrzeżach kupują osoby, dla których dostęp do infrastruktury społecznej, kulturowej, finansowej nie jest wartością, gdyż z niej nie korzystają. Zyskują większy metraż mieszkania, bardziej nowoczesną strukturę osiedla, kosztem jego usytuowania.

„Castells (1983) dowodzi, że dostęp do podstawowych usług publicznych, takich jak edukacja, opieka zdrowotna, mieszkalnictwo, techniczna infrastruktura komunalna, rekreacja oraz bezpieczeństwo, ma zasadniczy i bezpośredni wpływ na jakość życia ludzi” (Sagan 2017, s. 157). Można powiedzieć, że północna część Trójmiasta gwarantuje wyższą jakość życia ze względu na lepszy dostęp do szkolnictwa (bardziej elitarnych szkół, szkolnictwa na poziomie liceów czy wyższego), opieki zdrowotnej (na wyższym poziomie usługi w centrach, szpitale), rekreacji i kultury (kina, teatry, filharmonie, opery, kluby, w przypadku Trójmiasta-nabrzeże, wiele terenów zielonych, parków, ścieżki rowerowe), technicznej infrastruktury (możliwość szybkiego przemieszczania tramwajami, szybką koleją miejską, alternatywne arterie), infrastruktury związanej z rynkiem pracy (centra biznesowe, biura, urzędy, instytucje związane z kulturą, rekreacją, centra handlowe, restauracje itd.). Możliwość wysokiej jakości życia jest również bardziej dostępna poprzez oszczędność czasu (np. na dojazdy), pieniędzy, ale także swobodny przepływ informacji i możliwości realizacji siebie, rozwoju w wielu aspektach życia.

Jak pisze I. Sagan, „rynek mieszkaniowy jest podstawowym czynnikiem sprawczym segregacji przestrzennej. Typ zabudowy, stosunki własnościowe, koszt, jakość i poziom utrzymania mieszkań to elementy różnicujące charakter mieszkalnictwa nie tylko $\mathrm{w}$ podstawowym wymiarze schronienia, ale także w wymiarze symbolicznego elementu krajobrazu, inwestycji kapitałowej 
czy też zasobu, który wpływa na szanse życiowe i możliwości mieszkańców" (Sagan 2017, s. 82). Rodzi się pytanie, na ile możliwe jest z punktu widzenia działań społecznych, niwelowanie skutków tej segregacji oraz na ile ważne są działania rewitalizacyjne, które minimalizują skutki, ale tego podziału (społecznego, przestrzennego, kulturowego) de facto nie zmieniają. Nadal istnieć będzie centrum i peryferia, choć możliwe, że peryferia te nie będą przynosić tak dużej liczby szkód czy demoralizować, a mieszkanie tam będzie dawało szansę na lepsze życie młodszemu pokoleniu. Utopijne myślenie o całkowitym wyrównaniu szans pozbawiłoby działaczy społecznych energii do jakiegokolwiek działania w myśl zasady, że nigdy nie osiągnie się pożądanego pełnego efektu. Rodzi się także pytanie czy mieszkańcy peryferii są zainteresowani przenosinami do centrów życia społecznego i kulturowego, albo wymianą tkanki miejskiej.

Socjologowie miasta zwracają także uwagę na inne procesy segregacyjne, które powodują indywidualne konsekwencje zróżnicowania społecznego $\mathrm{w}$ dużych aglomeracjach. Są one związane $\mathrm{z}$ anonimowością, alienacją, anomią społeczną, dlatego tak ważne są działania rewitalizacyjne zapewniające integrację i zwiększanie poczucia bezpieczeństwa. Anna Karwińska wskazuje na następujące procesy: „Zagęszczanie się kontaktów, przy jednoczesnym ich urzeczowieniu i fragmentaryzacji, przyczynia się do negatywnych zjawisk psychologicznych, zaburzenia relacji międzyludzkich, powstawania poczucia osamotnienia i depresji. Jednocześnie wszystkie te czynniki: wzrost liczebności, gęstość i zróżnicowanie, sprzyjają procesom segregacji miasta i tworzenia typowo miejskiego wzoru przestrzeni, charakteryzującego się nasileniem kontrastów, tworzeniem wyodrębnionych sfer miasta, walką o najcenniejsze obszary" (Karwińska 2007, s. 40). Cechą zbiorowości miejskiej jest złożoność jej struktury, bowiem mamy do czynienia $\mathrm{z}$ różnymi podziałami: pochodzenia terytorialnego, etnicznego, religijności, zawodowego, zamożności, poziomu i stylu życia. W środowisku miejskim ze względu na duże zagęszczenie ludności tworzą się warunki do występowania i natężania zjawisk społecznych, gdzie indziej mniej i słabiej widocznych (Karwińska 2007, s. 40). Z drugiej strony pojawiają się wśród socjologów głosy, że to zróżnicowanie i obawa przed anonimowością, przyczynia się do tworzenia innego rodzaju więzi oraz ruchów społecznych. Jak pisze Anthony Giddens „mieszkańcy miast potrafią współpracować z ludźmi o podobnym pochodzeniu lub interesach i nawiązywać z nimi więzi lokalne; ponadto włączają się do różnych grup religijnych, etnicznych, politycznych i innych formacji subkulturowych" (2010, s. 599). Z jednej strony mówi się, że miasto jest światem ludzi obcych sobie, z drugiej strony, jak podkreśla Giddens podobieństwo kulturowe, językowe czy interesów oso- 
bistych, sprzyja aktywności, co nie jest tak oczywiste w przypadku wchodzenia $\mathrm{w}$ relacje z ludźmi mieszkającymi na wsi. Są oni powierzchownie uprzejmi, ale bardziej hermetyczni i nieufni w budowaniu bliższych relacji i w działaniu na rzecz dobra wspólnego. W dalszej części tekstu analizie zostanie poddana działalność sąsiedzka w różnych obszarach życia wielkomiejskiej społeczności.

Jak zwraca uwagę I. Sagan, bez interwencji państwa, nie jest możliwe rozwiązanie problemów mieszkaniowych społeczeństw, a także przeciwdziałanie segregacjom. Samorządy lokalne w Polsce nie dysponują wystarczającą liczbą mieszkań socjalnych czy komunalnych. Ich liczba jest daleka od niezbędnego minimum. Oferta ta dedykowana jest dla osób najuboższych, które nie są w stanie odłożyć na własne mieszkanie, na zaciągnięcie kredytu czy korzystanie z wsparcia państwa w postaci oferty Towarzystw Budownictwa Społecznego (TBS). Mieszkania te wymagają od mieszkańca pewnego wkładu własnego (zwrotnej kaucji), ponadto poświadczenia o zatrudnieniu i możliwości opłacania czynszu wraz z odsetkami kredytu zaciągniętego przez gminę na wybudowanie mieszkania. De facto mieszkania te są dość drogie, a tym samym niedostępne dla najuboższych. Ponadto nadmienić należy, że gminy wybudowały mieszkania TBS także na peryferiach (np. Gdańsk Szadółki, Bydgoszcz Fordon lub Osowa Góra). Taka interwencja państwa w obszarze polityki mieszkaniowej prowadzi m.in. do zamrażania cen czynszów, co dla sektora prywatnego nie jest korzystne ze względu na wysokie nakłady finansowe (wysokie ceny mieszkań) i długofalowe oczekiwanie na jakikolwiek zysk. Jak zauważa Sagan, polityka mieszkaniowa w kierunku włączania czy niwelowania różnic, wymaga interwencji państwa i może przybierać różnego rodzaju formy, np. tworzenie własnych zasobów mieszkaniowych (budownictwo komunalne), finansowe mechanizmy wspierania inwestycji mieszkaniowych (budownictwo społeczne, programy wspierania mieszkańców przy zakupie mieszkań czy ich wynajmie). Państwo polskie w 2018 roku zakończyło jeden z programów „Mieszkanie dla Młodych”, które było wsparciem dla ludzi młodych, pracujących i mających pewne zasoby finansowe, czyli także nie dla najuboższych (por. Sagan 2017, s. 86). Kolejny program „Mieszkanie plus” dedykowany jest osobom, które jeszcze nie mają swoich mieszkań, w którym gmina, podobnie jak w przypadku TBS, partycypuje $\mathrm{w}$ budownictwie mieszkań, miedzy innymi poprzez przekazanie działek pod budowę. Pod koniec roku 2018 oddano już około 10 tys. lokali. W Gdyni takie mieszkania powstają w dzielnicy Kacze Buki (niestety także jest to miejsce dalekie od centrum, $\mathrm{z}$ trudnym dojazdem i dopiero rozbudowującą się infrastrukturą). W krótkim czasie zgłosiło się 750 chętnych osób. Jednak dostępność tego rodzaju mieszkań jest dla osób biednych także ograniczona, wstępnie szacuje się bowiem, że czynsz mieszka- 
nia o metrażu $50 \mathrm{~m}^{2}$ będzie wynosił około $1100 \mathrm{zl}$, z możliwością uzyskania dofinansowania. Koszt takiego mieszkania jest bardzo wysoki, co stanowi znaczące utrudnienie dla potencjalnego użytkownika ${ }^{1}$.

Podsumowując, miejskie polityki mieszkaniowe pogłębiają proces segregacji społecznej (Sagan 2017, s. 92). Przekazywanie mniej atrakcyjnych gruntów na budownictwo wspierane i lokowanie mieszkań komunalnych lub socjalnych na peryferiach, tworzy swoiste przestrzenie nie tylko urbanizacyjne, ale także społeczne i kulturowe. „Polityki mieszkaniowe odpowiadają za społeczny dostęp do zróżnicowanych zasobów mieszkaniowych, ich jakości oraz rozmieszenia w przestrzeni miasta. [...] Zmniejszenie zasobów mieszkań komunalnych i udziału sektora publicznego $\mathrm{w}$ budownictwie społecznym oraz programach wspierania siły nabywczej poszczególnych grup społecznych na rynkach mieszkaniowych pogłębia podziały, pozbawiając słabsze ekonomicznie jednostki możliwości realizacji podstawowej potrzeby, jaką jest mieszkanie" (Sagan 2017, s. 92).

Innymi mechanizmami dzielenia społeczności poprzez dostępność do określonych miejsc jest ruch miejski związanych z zawłaszczaniem śródmieść, które mają symboliczny i sentymentalny wymiar. Jak pisze Sagan „stara zabudowa miejska jest dowodem na długą historię miasta, dostarcza ikon krajobrazowych wykorzystywanych jako symbole miasta i służących silnej z nim identyfikacji” (Sagan 2017, s. 104). W Trójmieście obserwuje się silne ruchy gentryfikacyjne $\mathrm{w}$ ostatnich latach. Coraz większą popularnością cieszą się nieruchomości w centrum, a tym samym „wypycha się" osoby biedne z tych dzielnic. Niekiedy zaobserwować można, że biedniejsi właściciele mieszkań sami je sprzedają (wartość nieruchomości wzrosła znacząco), gdyż nie posiadają środków na kosztowne remonty, a szeroko rozumiane centrum (z jego życiem kulturalnym, społecznym i innymi korzyściami), nie jest dla nich atrakcyjne i kupują mieszkania na obrzeżach, w nowszym budownictwie. Następuje zmiana mentalna i „(n)abywcami są na ogół ludzie młodzi, często profesjonaliści wykonujący wolne zawody, reprezentujący zarówno tradycyjne, jak i nietradycyjne gospodarstwa domowe, czyli niepełne rodziny, jednoosobowe gospodarstwa, związki partnerskie itp. Potencjał społeczny nowych mieszkańców, silnie zainteresowanych działaniami rewitalizacyjnymi, nie jest wykorzystywany w lokalnej polityce" (Sagan 2017, s. 108).

1 https://dom.trojmiasto.pl/Mieszkanie-Plus-w-Gdyni-Nabor-wnioskow-w-pazdzierniku -n127717.html. 


\section{Działania społeczne w kierunku animacji i rewitalizacji społecznej}

Jak pisze Bohdan Skrzypczak, idea i koncepcja rewitalizacji pojawia się w Polsce w latach 90. XX wieku. Pierwszy okres rewitalizacji to głównie działania renowacyjne, czyli remont substancji mieszkaniowej, renowacja zabytków i upiększanie architektoniczne przestrzeni publicznych. Kolejne działania to rewitalizacja gospodarcza, a dopiero w ostatnim etapie rozwoju rewitalizacji, już w XXI wieku, rewitalizacja społeczna, która ma na celu ożywienie życia społecznego w różnych formach i w celu integracji, wsparcia społecznego, włączania i przeciwdziałania wykluczeniu (por. Skrzypczak 2012, s. 5-6). Wzrost zainteresowania samorządów rewitalizacją nastąpił po akcesji Polski do struktur unijnych, dzięki której Polska mogła wnioskować o środki z funduszy strukturalnych, między innymi na priorytety związane $\mathrm{z}$ rewitalizacją (por. Wódź 2012, s. 41).

Działaniami, które z perspektywy polityki społecznej państwa i samorządów mają wyrównywać dysproporcje, ulepszać tkankę miejską w wielu wymiarach, zapobiegać demoralizacji życia czy stwarzać szansę na wymianę lub mixing w przestrzeni miejskiej, są działania rewitalizacyjne. Rewitalizacja rozumiana jest jako proces odnowy zdegradowanych fizycznie, ekonomicznie, społecznie i środowiskowo obszarów przestrzeni miejskiej. Działania samorządów zmierzają w kierunku równoważenia rozwoju miasta i „obejmuje elementy planowania i projektowania miejskiego, mieszkalnictwa, infrastruktury, w tym transportowej, polityki gospodarczej, w tym ekonomicznego wykorzystania zasobów kultury i turystyki miejskiej, rozwoju społeczności lokalnych oraz zasad zrównoważonego rozwoju" (Sagan 2017, s. 98). Przykładem takich działań są powszechne już obecnie budżety obywatelskie w miastach, gdzie społeczności mają możliwość wypowiadać się na temat zaspokajania potrzeb, które mają swoje odzwierciedlenie w zmianach przestrzeni miejskiej i tworzenia przestrzeni wspólnych.

By działania w obszarze pomocy społecznej były efektywne i trwałe winno się je projektować kompleksowo, udzielając wsparcia wielowymiarowego. B. Skrzypczak, definiując rewitalizację społeczną, zwraca uwagę na procesy zintegrowanej interwencji społeczno-edukacyjnej, która dotyczy terytorium o dużym natężeniu problemów społeczno-ekonomicznych (Skrzypczak 2012, s. 5). Rewitalizacją społeczną są najczęściej „działania skupione na ożywieniu zdegradowanych przestrzeniach miast, np. poprzemysłowych, których celem jest znalezienie dla nich nowego zastosowania i doprowadzenie do stanu, w którym obszary zmieniają swoją funkcję" (Skrzypczak 2012, s. 6). 
Warto zwrócić uwagę na istotę pracy środowiskowej, która stanowi element działań rewitalizacyjnych. Tomasz Kaźmierczak w swoim opracowaniu pisze, że ma ona poprawiać funkcjonowanie społeczne osób, na rzecz których jest podejmowana poprzez (z)modyfikowanie czynników środowiskowych. Autor wyróżnia dwa rodzaje modyfikacji. Pierwszy z nich to wszelkiego rodzaju zmiany społeczne i/lub zmiany w obrębie społeczności. Zmiany te mają poprawiać warunki życia i zaspokajać potrzeby członków społeczności. Mogą one dotyczyć struktury społeczności, składu, funkcji, granic i otoczenia. Natomiast drugi rodzaj modyfikacji dotyczy aktywizowania członków społeczności, mobilizowania do czynnego działania oraz uczestnictwa $\mathrm{w}$ życiu publicznym (Kaźmierczak 2015, s. 23-24).

Istotne jest uświadomienie sobie roli działaczy społecznych w przestrzeni miasta, zakresów odpowiedzialności i możliwości realizacji zadań pracowników socjalnych, animatorów społecznych, organizatorów społeczności lokalnej, a także polityków społecznych i ludzi biznesu (czy uwzględnienie mechanizmów rynkowych). Na powodzenie tych działań zwraca uwagę Ewa Marynowicz-Hetka, podkreślając wagę zasobów osób i możliwość uruchamiania sił społecznych. „Teren działania pracownika socjalnego warunkuje możliwość realizowania określonych zasobów (ludzi, urządzeń, instytucji). W tym sensie odmiennie układać się będzie działania pracownika socjalnego $\mathrm{w}$ różnych typowych środowiskach: na wsi, w mieście małym, aglomeracji miejskiej” (Marynowicz-Hetka 1980, s. 5).

Zmiany globalizacyjne i urbanistyczne spowodowały pojawienie się wielu niepożądanych, a wręcz patologicznych zjawisk. Zwracają na to uwagę w swojej publikacji Piotr Sztompka i Krzysztof Frysztacki, pisząc, że u progu XXI wieku pojawia się i utrwala wiele zjawisk patologicznych. Jest nim zanik etosu pracy, lekceważenie prawa, a promowanie cwaniactwa, osłabianie więzi lojalności, solidarności na rzecz pogardy do prawdy, ucieczka od zaangażowania w sferę publiczną na rzecz prywatnej, uleganie dogmatom i zawierzenie stereotypom. Niepokojącym zjawiskiem jest zauważalna zmiana w życiu codziennym. Przejawia się ona chamstwem, egoizmem, wrogością, niechlujstwem, brudem i bałaganem. Ponadto autorzy opracowania zwracają uwagę na rabunkowy, niszczycielski, eksploatacyjny stosunek do przyrody, a w obszarze kultury technologicznej niepokoi brak dbałości, precyzji, a czasem wręcz analfabetyzm technologiczny. Zjawiska te mają szerokie reperkusje w wymiarze życia społecznego (Frysztacki, Sztompka 2012, s. 6-7; za Marzec-Holka 2015, s. 43).

Świadomość tych procesów jest sytuacją wyjściową do projektowania narzędzi badawczych (diagnostycznych), a w myśl za tym, projektowanie wraz 
z uczestnikami życia społecznego działań społecznych, profilaktycznych, kompensacyjnych i naprawczych.

Zmiany urbanizacyjne i mentalne $\mathrm{w}$ architekturze Gdyni są zmianami, które następują powoli. Być może także dlatego, że nikt nie jest nimi zainteresowany, ani sami mieszkańcy Gdyni, ani tak do końca władze samorządowe czy pomoc społeczna. „Skutkiem i przyczyną nierównego wyposażenia przestrzeni miejskiej w usługi publiczne jest segregacja społeczna" (Sagan 2017, s. 157).

Taka struktura społeczna i urbanizacyjna jest charakterystyczna, jak pisze M. Mendel (2017), w trakcie tworzenia się miasta. Czas międzywojennego rozkwitu Gdyni, to czas budowania komfortu, przestrzeni i pełnej estetyki modernistycznej aglomeracji, utożsamianej z wolnością i komfortem swobody przestrzeni. Stąd szerokie ulice, place i niewielkie zagęszczenie w reprezentacyjnych częściach miasta (Mendel 2017, s. 105-106). Jednak jak dalej czytamy „Tysiące osób wznosiło to miasto, zamieszkując jednak jedynie jego obrzeża i tworząc dzikie osiedla, w których życie przebiegało poza wszelkimi standardami higienicznymi, zdrowotnymi i socjalnymi” (Mendel 2017, s. 105). W latach trzydziestych „niechciane, zaburzające estetykę” miasto prowadziło już odgórne przesiedlenia i plany urbanistyczne kierowały mieszkańców, głównie robotników na Witomino. Na dzień dzisiejszy można powiedzieć, ze najuboższa część miasta to nadal Chylonia i Grabówek (obrzeża miasta, położone blisko obwodnicy), gdzie większość ludności to potomkowie robotników oraz stoczniowców. Jak pisze M. Mendel, ludność żyje tam „reprodukując zarówno wzory rodzinne, jak i lokalną historię, także trwający w tych miejscach nastrój prowizorki, bylejakości i tymczasowości” (Mendel 2017, s. 107).

\section{Wybrane gdyńskie projekty rewitalizacji w obszarze działania społecznego}

Jak podkreśla I. Sagan „proces rehabilitacji mentalnej dzielnic uznanych za złe i społecznie zdegradowane trwa znacznie dłużej niż ich fizyczna rewitalizacja. Społeczna segregacja przestrzeni miast jest niezwykle trudna, jeśli w ogóle możliwa do przezwyciężenia" (Sagan 2017, s. 82). W niniejszym tekście chciałabym zaprezentować kilka pozytywnych działań, które w sposób planowy, ale efektywny, zmieniają przestrzeń społeczną uznanych za zdegradowane osiedla. Dzieje się tak, jak podkreśla autorka, powoli, jednak działanie to nie jest skazane na porażkę.

Castells uważa, że to państwo jest odpowiedzialne za uprzywilejowane politycznie sfery konsumpcji zbiorowej, co wywołuje zbiorowy aktywizm, 
tworzenie organizacji pozarządowych oraz inne formy mobilizacji społecznej, które dają wyraz sprzeciwu (Castells 1983 za: Sagan 2017, s. 157), czego wynikiem są między innymi działania opisanych poniżej organizacji oddolnych.

Pisząc o gdyńskich projektach rewitalizacyjnych należy zwrócić uwage na kilka obszarów. Pierwszy z nich dotyczy projektu rewitalizacji tak zwanego „Pekinu”, drugi rewitalizacji dzielnic Grabówka i Chyloni oraz projektu Utrecht, dedykowanemu osobom bezdomnym, w większości wywodzącym się z „Pekinu”, Chylonii, Grabówka lub aktualnie zamieszkujących w tych dzielnicach.

„Pekin” w gdyńskiej rzeczywistości tworzyły baraki, altanki, domki, które zostały częściowo wybudowane $\mathrm{w}$ latach międzywojennych przez robotników na ziemiach Nikielskiego, który wyraził zgodę, by jego robotnicy tymczasowo zamieszkali w barakach bez dodatkowych opłat, a czynsz odpracowywali. Miały istnieć od 3 do 5 lat. Do rozbiórek jednak nie doszło. Wybuchła II wojna światowa, a po objęciu władzy przez komunistów, ludność osiedliła się tam ponownie. Niedawno niektóre rodziny rozbudowały i zmodernizowały swoje domy. W ostatniej dekadzie ziemia, na której mieszczą się te budynki, została odziedziczona przez cztery osoby. Rada Miasta ziemie te przekształciła na tereny pod zabudowę mieszkalną i właściciele zdecydowali, że ją sprzedadzą, pozbywając się "dzikich lokatorów”. Nadmienić trzeba, że wiele osób tam zamieszkujących nie miało umów dzierżawy ziemi, umów z zakładami komunalnymi i energetycznymi. Oznaczało to, że mieszkali tam nielegalnie, bez meldunków, pobierając nielegalnie prąd (kradnąc go), a nieczystości odprowadzali do kanałów deszczowych. Władze miasta podjęły projekt jedynie rewitalizacji społecznej, gdyż nie są właścicielami gruntów, więc nie mają podstaw prawnych do ochrony mieszkańców w zakresie legalizacji ich pobytu. Rewitalizacja odbyła się wielotorowo. Ponad 20 rodzin otrzymało mieszkania socjalne, część otrzymuje dopłaty do wynajmu mieszkań na wolnym rynku, a także pomoc w znalezieniu lokali pod wynajem. Prowadzona jest również aktywizacja zawodowa, gdyż wielu tamtejszych mieszkańców nie pracuje od lat. Prezydent Miasta Michał Guć wypowiadał się w mediach, że ma świadomość, iż wsparcie finansowe w zakresie najmu będzie w przypadku wielu osób dożywotnie, szczególnie dla seniorów i osób $\mathrm{z}$ niepełnosprawnością. Jeszcze $\mathrm{w}$ listopadzie 2018 roku w barakach zamieszkiwały 64 rodziny, 81 już były zabezpieczone, ale akcja wyburzania domków, altanek i baraków trwa².

2 https://www.trojmiasto.pl/wiadomosci/Gdynia-przedluza-wsparcie-dla-mieszkancowPekinu-n129493.html. 
Przykładem powrotu do korzeni wspólnot sąsiedzkich jest działalność jednej z gdyńskich fundacji. Na istotę tych relacji oraz niebezpieczeństwo ich niszczenia zwraca uwagę M. Mendel pisząc, że wspólnoty te są dzisiaj rozbijane $\mathrm{w}$ ramach neoliberalnego zarządzania miastami, które podporządkowane jest „nie potrzebom mieszkańców, lecz warunkom obrotu wartością parceli, którą w mieście zajmują" (Mendel 2017, s. 48).

Na obszarach zdegradowanych i tych, o których pisze M. Mendel jako obszarach peryferii, w gdyńskich dzielnicach Grabowo, Chylonia, Brętowo, Dąbrowa działa od 2011 roku Fundacja „Kreatywni”, która w swoich założeniach statutowych ma między innymi na celu rewitalizację we wszystkich możliwych obszarach zmiany: profilaktykę, poradnictwo, aktywizację społeczną, animację, organizowanie społeczności lokalnej, przeciwdziałanie wykluczeniu społecznemu, budowanie świadomego społeczeństwa, gotowego na odpowiedzialne podejmowanie wyzwań, stawianych przez postmodernistyczną rzeczywistość. Fundacja realizuje swoje cele między innymi poprzez działania animacyjne, socjoterapeutyczne, streeworking, poradnictwo pedagogiczne i psychologiczne, szkolenia, wolontariat (także międzynarodowy), organizowanie społeczności lokalnej. Nawiązując do założeń pedagogiki społecznej Radlińskiej, ważne jest, by wzmacniać zasoby indywidualne uczestników życia społecznego, by siłami społecznymi możliwe było wyrównywanie szans uczestników społeczności lokalnej, budowanie spójności społecznej, wzmacnianie zasobów lokalnego środowiska, pomoc w odkrywaniu potencjału osób, a także wyposażanie ich w wiedzę i umiejętności, które pozwolą im łatwiej odnaleźć się w życiu osobistym i zawodowym. Działania te Fundacja realizuje w perspektywie międzypokoleniowej i międzysektorowej.

Obecnie Fundacja działa w następujących stałych formułach: Klub Osiedlowy „Apteka” i Klub Młodzieżowy „Kreatywni” przy ulicy Opata Hackiego (Grabówek) oraz cztery Placówki Wsparcia Dziennego (Chylonia, Dąbrowa, Oksywie, Brętowo). Działania Klubu Osiedlowego, skierowanego zarówno dla dorosłych, jak i do młodzieży, oscylują wokół działań związanych ze wzrostem zaangażowania społecznego poprzez szkolenia, poradnictwo, organizowanie do samopomocy (np. w ramach Banku Żywności, budowania indywidualnej sieci pomocy, stałej akcji „Daj rzeczy drugie życie”). Osoby uczestniczące w działaniach Klubów są przygotowywane do nowych ról społecznych, by w przyszłości sami stali się animatorami życia społecznego. Procesy rewitalizacyjne odbywają się zarówno na poziomie mentalnym, jak i współtworzenia przestrzeni materialnej. Mieszkańcy uczestniczyli w planowaniu placów zabaw, skwerów w dzielnicy Chylonia (aktualnie prowadzone są już zaawansowane prace realizacyjne przez miasto), termomodernizacji bloków, a także tworzenia Domu Sąsiedzkiego w jednym z wolnych budynków. 
Od lat istotnymi działaniami Klubu Osiedlowego jest systematyczny udział $\mathrm{w}$ działaniach profilaktycznych a także wspierających mieszkańców w obszarze przeciwdziałania przemocy oraz profilaktyki uzależnień. Ma to swoje odzwierciedlenie między innymi w udziale klubowiczów w grupach roboczych do spraw przeciwdziałania przemocy, opieki nad rodziną, grupach algorytmowych do spraw przemocy, a także $\mathrm{w}$ tworzeniu modelu pracy $\mathrm{z}$ rodziną i osobą z zaburzeniami psychicznymi.

W zakresie swoich zadań statutowych Fundacja organizuje zarówno działania stałe, jak i cykliczne, które wpisały się już w kalendarz imprez. Jest to między innymi zbiórka WOŚP, Liga Podwórkowa, Pchli Targ, wsparcie w ramach Banku Żywności, Europejski Dzień Sąsiada, Europejski Dzień Solidarności Międzypokoleniowej, Parada Godności oraz wszelkie imprezy związane ze świętami (bożonarodzeniowymi, imprezy karnawałowe, wielkanocne, dzień matki, dzień dziecka itp.). Istotne jest też to, że działania te mają wymiar samopomocy i samoorganizacji, dzięki powtarzalności, trwałości w życiu społecznym dzielnicy, ale także i międzypokoleniowy, gdzie oba kluby współpracują w realizacji większości działań.

Analizując sprawozdania merytoryczne Fundacji oraz rozmowy przeprowadzone z Prezeską Aleksandrą Mróz-Wykusz, uczestnikami działań, podczas wizyt studyjnych ze studentami, stwierdzić można, że aktywność społeczności rokrocznie wzrasta, zwiększa się zaangażowanie i współodpowiedzialność, czemu sprzyja powtarzalność i stałość działań oraz poczucie sprawstwa. W ostatnim roku odbyły się liczne konsultacje także na temat polityki senioralnej oraz szkolenia na temat rewitalizacji.

Placówki Wsparcia dziennego realizują głównie działania profilaktyczne, socjoterapię, poradnictwo pedagogiczne i psychologiczne dla dzieci i ich rodziców. Wspierają dzieci w edukacji (korepetycje i wspólne odrabianie lekcji), organizują dodatkowe zajęcia $\mathrm{z}$ języków obcych i sportowe, a także zapewniają uczestnictwo w kulturze (np. poprzez warsztaty teatralne, fotograficzne, wyjścia do kina, współpracę z Muzeum Emigracji). Działania te wpisały się na stałe w obraz dzielnicy, są realizowane intensywnie w ciągu roku szkolnego (36 godzin tygodniowo), ale także podczas wakacji (kolonie i półkolonie dla dzieci).

Fundacja wpisuje się także w działania koalicyjne, dzięki temu nie zamyka się jedynie $\mathrm{w}$ obrębie dzielnicy, ale także korzysta $\mathrm{z}$ innowacji, a niekiedy wręcz je tworzy. Od lat mieszkańcy współpracują z wolontariuszami z Gdyni. Realizowany jest tam wolontariat międzynarodowy, dzięki któremu poznają inną kulturę, język, kuchnię i korzystają z różnorodnych zasobów wolontariuszy. Fundacja współpracuje z Uniwersytetem Gdańskim w obszarze tworzenia programów nauczania, realizacji tego nauczania w praktycznym wymiarze, czy 
włączania w działania animacyjne studentów pracy socjalnej. Stałym partnerem są Miejski Ośrodek Pomocy Społecznej, gdyńskie muzea, Teatr Muzyczny, Urząd Miasta wraz z Laboratorium Innowacji Społecznych ${ }^{3}$.

W ramach projektów socjalnych, które mają w swoich założeniach także rewitalizację społeczną, Gdynia od trzech lat realizuje projekt socjalny o nazwie Utrecht, dedykowany osobom bezdomnym. Podstawowym założeniem projektu jest wsparcie osób bezdomnych w samodzielnym zamieszkaniu w wynajmowanych, samodzielnie wybranych mieszkaniach/pokojach, w myśl zasady - najpierw mieszkanie. Osoba, która jest gotowa na takie wyzwanie, otrzymuje wsparcie $\mathrm{w}$ szukaniu mieszkania oraz $\mathrm{w}$ finansowaniu jego najmu (przez pierwsze trzy miesiące $100 \%$ kosztów samodzielności osoby pokrywa MOPS Gdynia). W dalszej kolejności działania projektowe obejmują intensywną aktywizację zawodową, optymalizację opieki i włączanie osób bezdomnych w życie społeczne. Dla osób bezdomnych jest to szansa na samodzielność, okazanie im zaufania, a dla gminy ogromne oszczędności, gdyż instytucjonalna pomoc jest zawsze droższa niż wsparcie środowiskowe w usamodzielnianiu. Część tych zaoszczędzonych środków przekazanych zostaje na realizację działań projektowych, takich jak wsparcie psychologiczne, prawne oraz finansowe (głównie na utrzymanie, remonty). W ramach ewaluacji projektu, po trzech latach realizacji projektu, dostrzeżono konieczność rozwijania umiejętności społecznych uczestników projektu, którzy sygnalizują, że największą dla nich trudnością jest poczucie samotności (stąd powrót niektórych do schronisk - do towarzystwa $)^{4}$. Kolejne działania będą wzbogacone o takie, które pomogą zagospodarować czas wolny i tworzyć przestrzenie dla budowania relacji z innymi. Obecnie 60 osób całkowicie się usamodzielniło, a kolejnych 60 jest w trakcie tego procesu. Warto dodać, że osoby wychodzące $\mathrm{z}$ bezdomności uczestniczą także $\mathrm{w}$ niekonwencjonalnych działaniach, a także swoistej profilaktyce bezdomności, realizując projekt teatru Gdynia Główna. W ramach działań projektowych uczestniczyli w warsztatach teatralnych, a teraz sami piszą sztuki, grają w swoich spektaklach i wystawiają je na Dworcu Gdynia Główna5

\section{Podsumowanie}

Miasta od zawsze były obszarem segregacji ze względów ekonomicznych, społecznych i kulturowych. Procesy te nie są ani specyficzne dla Pol-

\footnotetext{
https://kreatywni.ngo/o-fundacji/sprawozdania.

http://www.mopsgdynia.pl/1854-nagroda-dla-gdyni-w-konkursie-teraz-projekt-socjalny.

https://www.gdynia.pl/spoleczenstwo,7580/3-lata-gdynskiego-utrechtu,529698.
} 
ski, ani dla obecnych czasów. Jak pisze A. Giddens ruchy miejskie na świecie mają swoją dynamikę i zmienne kierunki (Giddens 2010), od rozwoju przedmieść po upadek śródmieść, by po latach kumulacja problemów społecznych i urbanistycznych, kierowała politykę ku uszlachetnianiu i „recyklingowi urbanistycznemu". Problemy urbanizacyjne mają swoje skutki gospodarcze, środowiskowe oraz społeczne, co dla pedagogiki społecznej i pracy socjalnej stanowi wyzwanie. W aktualnej polskiej rzeczywistości zaobserwować można ruchy miejskie w kierunku wykluczania poprzez zamieszkanie na peryferiach, obrzeżach miast. Centra zarezerwowane są dla osób zamożnych, o wysokich zarobkach i statusach. W centrach także lokuje się biznes, kultura, edukacja, modne usługi i komercja. Dzięki wieloletnim działaniom uszlachetniania urbanistycznego (remontom, rewitalizacjom architektury) zmienił się obraz centrów miast, w tym opisywanej w tym artykule Gdyni oraz wspomnianego jedynie Gdańska. Mechanizmy polityki społecznej państwa i gmin nie gwarantują przeciwdziałania segregacji, a rynek nieruchomości jedynie je pogłębia. Działania państwa wspomagające obywateli w pozyskiwaniu nieruchomości są znikome i nie spełniają do końca swojej funkcji, a zasoby gminy są zbyt małe, by z własnych zasobów tworzyć substancję mieszkaniową w postaci mieszkań socjalnych i komunalnych.

Działania rewitalizacyjne w mieście są działaniami koniecznymi i wpisującymi się w działalność pedagogiczną i animacyjną służb społecznych oraz organizacji pozarządowych. O celach i znaczeniu działań aktywizujących pisał Wierzbicki, dla którego „aktywizacja i rozwój społeczności lokalnych jest działalnością ludzi zamieszkałych na danym terytorium, którzy wspólnym wysiłkiem pragną zaspokoić swe potrzeby oraz poprawić zarówno warunki swojego życia, jak i warunki bytowania grupy lokalnej, głównie poprzez tworzenie nowych struktur; w procesie ich powstawania członkowie nabywają nowych umiejętności, postaw i poglądów" (Wierzbicki 1973, s. 20). Stanowi ona przeciwwagę i profilaktykę procesów segregacyjnych i wykluczających.

Prezentowane projekty rewitalizacyjne, realizowane w Gdyni, uruchamiają wiele działań, od wsparcia finansowego, poprzez aktywizację zawodową, społeczną, a także edukację do partycypacji. Warto zwrócić uwagę na fakt, że są to działania realizowane przez różne podmioty (gminę, organizacje pozarządowe) i dedykowane są różnym grupom mieszkańców. Są to osoby bezdomne, bezrobotne, seniorzy, ale także dzieci i młodzież. Międzygeneracyjność działań aktywizujących ma różne wymiary i funkcje. Daje młodym ludziom szansę na wyrównywanie szans rozwojowych, ale także kształtuje postawy obywatelskie, tworzy przestrzeń do społecznej odpowiedzialności, integruje i wskazuje na korzyści z bycia aktywnym mieszkańcem. 


\section{Literatura}

Frysztacki K., Sztompka P. (red.), (2012), Polska początku XXI wieku: przemiany kulturowe i cywilizacyjne, Warszawa.

Giddens A., (2010), Socjologia, PWN, Warszawa.

Karwińska A., (2007), Miejski collage. Wariant postsocjalistyczny, [w:] Socjologia miasta. Nowe dziedziny badań, A. Majer (red.), Wydawnictwo Uniwersytetu Łódzkiego, Łódź, s. 39-54.

Kaźmierczak T., (2015), Praca środowiskowa - materialy do definicji sprawozdawczej, „Praca Socjalna”, 3, s. 20-34.

Marynowicz-Hetka E., (1980), Praca socjalno-wychowawcza $z$ rodzina niepetna, Instytut Wydawniczy CRZZ, Warszawa.

Marzec-Holka K., (2015), Kapitał społeczny a wspólnoty wiejskie w obronie „małych szkół”. Przykład województwa kujawsko-pomorskiego, Wydawnictwo Uniwersytetu Kazimierza Wielkiego, Bydgoszcz.

Mendel M., (2017), Pedagogika miejsca wspólnego, Wydawnictwo Naukowe Katedra, Gdańsk.

Sagan I., (2017), Miasto: nowa kwestia i nowa polityka, Wydawnictwo Naukowe Scholar, Warszawa.

Skrzypczak B., Łukowski W. (red.), (2012), Rewitalizacja społeczna - od aktywizacji do rozwoju lokalnego, Wydawnictwo Naukowe Instytutu Technologii Eksploatacji - Państwowy Instytut Badawczy, Radom.

Wierzbicki Z.T. (red.), (1973), Aktywizacja i rozwój społeczności lokalnych, [w:] Aktywizacja i rozwój społeczności lokalnych, Ossolineum, Wrocław.

\section{Źródła internetowe}

https://dom.trojmiasto.pl/Mieszkanie-Plus-w-Gdyni-Nabor-wnioskow-w-pazdzierniku-n127717. html (data pobrania: 21.12.2018).

https://kreatywni.ngo/o-fundacji/sprawozdania (data pobrania: 21.12.2018).

https://www.gdynia.pl/spoleczenstwo,7580/3-lata-gdynskiego-utrechtu,529698 (data pobrania: 14.12.2018).

http://www.mopsgdynia.pl/1854-nagroda-dla-gdyni-w-konkursie-teraz-projekt-socjalny (data pobrania: 14.12.2018).

https://www.trojmiasto.pl/wiadomosci/Gdynia-przedluza-wsparcie-dla-mieszkancowPekinu-n129493.html (data pobrania: 14.12.2018). 